BULLETIN Bulletin hispanique

HISPANIQUE Université Michel de Montaigne Bordeaux

110-1 | 2008

Varia

\title{
El Libro de buen amor y el Facet catalán
}

Jacques Joset

\section{OpenEdition}

Journals

Édition électronique

URL : https://journals.openedition.org/bulletinhispanique/644

DOI : 10.4000/bulletinhispanique.644

ISSN : 1775-3821

Éditeur

Presses universitaires de Bordeaux

Édition imprimée

Date de publication : 1 juin 2008

Pagination : 279-282

ISBN : 978-2-86781-511-9

ISSN : 0007-4640

Référence électronique

Jacques Joset, «El Libro de buen amor y el Facet catalán », Bulletin hispanique [En ligne], 110-1 | 2008, document 9, mis en ligne le 01 juin 2011, consulté le 18 septembre 2021. URL : http://

journals.openedition.org/bulletinhispanique/644; DOI : https://doi.org/10.4000/bulletinhispanique. 644

Tous droits réservés 


\title{
VARIÉTÉS
}

\section{El Libro de buen amor y el Facet catalán}

\author{
JACQUES JOSET \\ Université de Liège
}

Entre le Libro de buen amor et la version catalane du Facetus, manuel de courtoisie connu, on note de curieux parallélismes expressifs qui ont statut d'interdiscours s'ils n'ont pas celui d'intertextes.

Entre el Libro de buen amor y la versión catalana del Facetus, conocido manual de cortesía, se advierten notables paralelismos expresivos, que tienen estatuto de interdiscursos cuando no de intertextos.

There are peculiar expressive parallels between the Libro de buen amor and the Catalan version of the Facetus, a well-known courtesy book. They are interdiscourses if not intertexts.

Mots-clés : Libro de buen amor - Facet catalan - Intertextualités.

T As intertextualidades e interdiscursos posibles entre la obra de Juan Ruiz Ly la literatura occitana ya fueron objeto de los cuidados filológicos de Félix Lecoy en sus clásicas Recherches sur le "Libro de buen amor», publicadas en 1938, cuando ni siquiera existían las palabras ${ }^{1}$. Menos presencia en las "fuentes " conocidas del Libro de buen amor tiene según Lecoy la literatura medieval catalana cuyos vínculos estrechos con la del Sur de Francia son sin embargo tópicos.

1. Félix Lecoy, Recherches sur le «Libro de buen amor» de Juan Ruiz, Archiprêtre de Hita, París, Droz, 1938.

$B H i$, Tome $110, \mathrm{n}^{\circ} 1$ - juin 2008 - p. 279 à 282. 
Recientemente Luis Suárez Fernández puso de manifiesto el lullismo que hubiera empapado la vida intelectual de la Península ibérica del siglo XIV. Las doctrinas expuestas por Ramón Llull en el Concilio de Viena del Delfinado en 1311 se difundieron luego por Castilla donde las recogieron Juan Ruiz y Juan Manuel. Su impronta es tal que aquél «no es capaz de librarse ni por un momento de su influencia $»^{2}$. La radicalidad de la propuesta extrańa tratándose de una personalidad literaria como la del Arcipreste que se caracteriza precisamente por la pluralidad de influjos controlados con la sabiduría poética de un gran maestro. No por eso hay que descartar toda forma de contacto entre las obras de Ramón Llull y de Juan Ruiz: dejo abiertas, por ejemplo, las posibilidades interdiscursivas o, por qué no, intertextuales que uno tejería con bastante fundamento entre el Blanquerna (¿1283-1286?), el Fèlix o Libre de meravelles (h. 1288-1289) y nuestro Libro de buen amor ${ }^{3}$.

Una adaptación catalana del siglo XIV del Facetus, manual de cortesía de hacia 1170, que no llamó la atención de Lecoy, llamará ahora la nuestra: ese Facet, ha de colocarse, más allá del original latino, en la literatura postovidiana en lenguas romances. Presenta paralelismos expresivos con el Libro de buen amor más ceñidos que las enunciaciones correspondientes del Facetus ya observados por José M. Martínez Torrejón ${ }^{4}$, quien, sin embargo, pasó por encima de « coincidencias » que, quizá, no lo son.

La más llamativa, por supuesto, es el empleo de la expresión bon' amor ("Aço es senyal de bon' amor", v. 786) 5, probablemente en el sentido de 'amor cortés', que ha de agregarse a la gavilla catalana que hace años había cosechado ${ }^{6}$. Como el Arcipreste (1703ab), el anónimo adaptador catalán menciona a Tristán y Flores, los enamorados par excellence, entre Virgilio

2. Luis Fernández Suárez, "El espacio ambiental del Arcipreste", in R. Amran (ed.), Autour du "Libro de buen amor", París, Indigo / Université de Picardie Jules-Verne, 2005, pp. 117-125 (cita de la p. 120).

3. Las fechas hipotéticas las propone Martín de Riquer, Literatura catalana medieval, Barcelona, Ayuntamiento, 1972, p. 34.

4. Véase José M. Martínez Torrejón, «El Libro de buen amor y un manual de cortesía: el Facetus 'Moribus et vita' ", in Anuario de Letras, XXV, 1987, pp. 65-90.

5. El Facet catalán lo publicó Alfred Morel-Fatio, «Mélanges de littérature catalane. III. Le livre de courtoisie ", in Romania, XV, 1886, pp. 192-235. Entresaco las citas de esa edición.

6. Jacques Joset, "Le 'bon amors' occitan et le 'buen amor' de Juan Ruiz, Arcipreste de Hita (Réflexions sur le destin d'une expression 'courtoise')", in Actes du VI Congrès international de langue et littérature d'oc et d'études franco-provençales. Montpellier septembre 1970, Montpellier, Centre d'estudis occitans-Revue des langues romanes, 1971, pp. 349-368 y Nuevas investigaciones sobre el "Libro de buen amor», Madrid, Cátedra, 1988, pp. 129-147. 
-otro parangón del amante, lujurioso a la verdad, para Juan Ruiz (cc. 257269) - y Jaufre Rudel, cuya fama debía de ser bastante apagada en la Castilla del siglo XIV:

\author{
Tot hom vos sera acusador \\ E Virgili primerament, \\ Tristany e Floris exament, \\ E [En] Jaufre Rudel de Blaya \\ Qui mori per sa dona gaya [...] \\ $(\text { vv. } 811-815)^{7}$
}

Los nombres, lo vimos ya, son tópicos pero en un texto que acumula los encuentros con el Libro de buen amor, éste no deja de ser singular. Como lo es el hecho de que a la mensajera del Facet se la llama «destral» (v. 478), que si bien en catalán significa 'hacha', también vale 'guía, cabestro, jáquima' ${ }^{8}$, siendo de la familla etimológica de cast. (a)destrar, diestro. Alfred MorelFatio da esta información semántica y trae a colación a Celestina ${ }^{9}$. El lector de Juan Ruiz vislumbra más bien una especie de esbozo del retrato de Trotaconventos en esta «destral», cuyos rasgos ya se alejan del modelo de la vetula ovidiana ${ }^{10}$, mientras la voz que la nombra evoca la famosa serie trainel, cabestro, cordel, guia, ... apodos de la Urraca del Libro de buen amor (cc. 924-927).

Volviendo a los tópicos comunes, el de la riqueza del reino de Francia $(L B A, 1244 \mathrm{c})$ no puede soslayarse («Plus ric me farets ses duptansa / Que quim daval regne de Fransa», Facet, vv. 796-797) como tampoco la comparación entre el cazador de conejos o liebres, que se afana en vano por coger el animal, y el marido engańado:

Pedro levanta la liebre e la mueve del covil, non la sigue nin la toma, faz' como cazador vil; otro Pedro que la sigue e la corre más sotil tómala: esto contesçe a caçadores mill.

$(L B A, \text { c. } 486)^{11}$

7. Se vuelven a mencionar a «Tristany» y «Virgili», v. 846, y a "Tristany l'anamorat», v. 1001.

8. Lo que da lugar a un juego de palabras en los vv. 570-571 del Facet: «La destral sia tan aguda / A dos colps l'arbre s'en adula.»

9. A. Morel-Fatio, art. cit., pp. 194-195.

10. Se leerán al propósito los vv. 478 ss., 935 ss. y 1102 ss. del Facet.

11. Cito el Libro de buen amor por mi edición (Madrid, Taurus, "Clásicos Taurus, 1», 1990). 
Diu hom que tu batras les mates,

Los rromanins e bulafagues

E altre aura los conylls.

(Facet, vv. 1545-1547)

Es de notar que siguen estos versos un dicho castellano: «Be saps que diu lo casteylano / Que fembra fa lo desgui[s]ado.» (vv. 1549-1550) ${ }^{12}$, que no deja de recordar la advertencia de Trotaconventos a Garoza: «Señora, diz la vieja, desaguisado façedes» (1386a). Morel-Fatio databa sin certidumbre ni precisión ese Facet catalán de la segunda mitad del siglo XIV ${ }^{13}$. En vista de lo aducido aquí, no me parece descaminado preguntarnos si no convendría adelantar la fecha de la obra de medio siglo, ya que es muy dudoso que un adaptador de un manual de cortesía acudiera a un libro atípico como el Buen amor, mientras sabemos de sobra que Juan Ruiz disfrutaba con los imitadores de Ovidio en cualquier lengua (neo)latina que escribiesen y no dejaba de coger en ellos granitos que sembraría en su propio Libro.

12. Introduzco en el texto la corrección sugerida en nota por A. Morel-Fatio, art. cit., p. 218.

13. Íd., p. 192. 